\title{
Doing African Christian Theology: Some Non-negotiable Essentials
}

\author{
Isaac Boaheng 1 \\ 1 Department of Theology - Christian Service University College, Ghana, Kumasi - Ghana.
}

\begin{abstract}
Missionary Christianity was introduced into Africa by Western and American missionaries whose theological framework shaped Christianity in Africa. Since theology is contextually informed, missionary theological formulations failed to meet Africa's needs in many respects. In response, the African church began a quest for an African-brewed theology that is culturally sensitive and contextually relevant. For some time now this quest has engaged many African scholars; yet, no scholarly consensus has been reached regarding the nature and methodology for African Christian theology. This article contributes to the ongoing discourse by examining the emergence and development of African Christian theology and afterward, outlining some essential features that must characterize African Christian theology to make it accessible to and acceptable by the African Christian community. It is a literature research based on critical examination of related publications on African Christian theology. The article offers a model for contemporary Christians who are engaged in or desire to undertake theological research for the benefit of Christianity in Africa.
\end{abstract}

Correspondence:

Isaac Boaheng

Email: revisaacboaheng@gmail. com

Publication History

Received 30th November, 2021, Accepted 14th December, 2021,

Published online 23rd December, 2021.

Keywords: Africa, Christian, Pan-Africanism, Theology, Worldview

(C) 2021 The Author(s). Published and Maintained by Noyam Publishers.

This is an open access article under the CCBY license (http://creativecommons.org/licenses/by/4.0/).

\section{INTRODUCTION}

The word "theology" comes from the Greek words "theos" ("God") and logos ("discourse" or "speech"). "Theology" therefore literally means discourse or speech about God or simply put, theology is the study of God. It was ancient Greek poets who first used the term "theology" in connection with myths about pagan gods. ${ }^{1}$ Those who wrote about the Greek pagan gods and their exploits were referred to as theologoi ("theologians"). Pherecydes of Syros was a Greek thinker who introduced the term theology in Greek literature. Aristotle applied the term "theology" to his first philosophy. Homer, Hesiod and Orpheus theologized through the poems and songs they wrote about pagan gods and divine things.

In Christian literature, Clement of Alexandria, a second-century Christian scholar, was the first to use "theology" in reference to acquiring true knowledge of the one true God. ${ }^{2}$ Augustine of Hippo (a fifthcentury theologian) applied "theology" to the study of "temporal rather than eternal matters." 3 St. Anslem of

\footnotetext{
1 Samuel Waje Kunhiyop, African Christian Theology (Nairobi: WordAlive Publishers, 2012), 1.

2 Kunhiyop, African Christian Theology, 1.

3 Kunhiyop, African Christian Theology, 1.
} 
Canterbury (1034-1109) defined theology as Fides quaerens intellectum ("Faith, seeking understanding"). ${ }^{4}$ This means one's faith in Christ prompts a quest for a deeper understanding of Christ and his salvation. The faith-seeking-understanding enterprise employs language, human thinking, human values, human ideals and traditions. Anselm hoped to understand his faith and the God of his faith. He puts it as such: "For I do not seek to understand so that I may believe; but I believe so that I may understand." ${ }^{5}$ This understanding results in improved human-divine, human-human and human-environment relationships. Peter Abelard (1079-1142) used "theology" in reference to a collection of various Christian teaching; he also use "theology" in a more technical sense to distinguish sacred learning from secular learning. ${ }^{6}$ Paul Tillich defined theology as "the statement of the truth of the Christian message and the interpretation of this truth for every new generation." 7 The idea that the Christian message needs to be interpreted for every new generation is suggestive that Christian theology must speak to issues related to the setting in which it is formulated. Charles C. Ryrie defined it as "thinking about God and expressing those thoughts in some way." ${ }^{8}$ Charles Hodge defined theology as "the exhibition of the facts of Scripture in their proper order and relation with the principles or general truths involved in the facts themselves, and which pervade and harmonize the whole." Hodge emphasizes the logical and coherent arrangement of theological thoughts. Based on these scholarly definitions, the working definition for theology for this paper is as follows: Theology is the (re)interpretation of Christian faith (in a coherent and logical manner) to speak to contemporary situations. Such an interpretation has past, present and future dimensions.

Based on the definition of theology outlined above, African Christian theology (or African Christian theology) may be considered as the reflection of known truth about God from an African socio-cultural perspective. John S. Mbiti defines African theology as the theological reflection by African Christians..$^{10}$ African Christian theology may be embarked upon by Africans or non-Africans with an adequate understanding of the African socio-cultural context and are seeking to address African needs. This paper purposes to outline some essential features that must characterize African Christian theology.

\section{Origins and Development of African Christian Theology Historical Antecedence of African Christian Theology}

In a sense, African Christian theology is as old as Christianity itself in Africa. African Christian theology began at the same time that the Gospel was preached to Africans. Christianity was introduced into the continent of Africa as early as the first century during the apostolic age when Africans who were present in Jerusalem on the Day of Pentecost returned to their countries and shared the Christian faith with others. As they shared the Gospel with others in their own languages, Africans began to formulate their own theology to meet their contextual needs. This is so because any successful cross-cultural missionary enterprise requires the translation of the Gospel into the new environment, taking into consideration the worldview and existential realities of the receptor community.

The city of Alexandria in Egypt and Western North-Africa (the area of present-day Algeria) were among the major centers of theological reflections in the early church. ${ }^{11}$ Alexandria was the center for Jewish leaning; the first translation of the Hebrew Bible took place at Alexandria to produce what is referred to as the Septuagint (LXX). Africa produced prominent theologians in the early Christian era, including Irenaeus of Lyons, Athanasius, Tertullian, Origen (c. 185-254 AD), Clement (c. 150-215 AD) and Augustine of Hippo

\footnotetext{
4 Anselm of Canterbury, "Proslogion" translated by M. J. Charlesworth in The Major Works, ed. Brian Davies and G. R. Evans pp. 82-104.(Oxford: Oxford University Press, 1998), 87.

5 Anselm of Canterbury, "Proslogion," 87.

6 Stephen F. Brown, "Medieval Theology" InThe Blackwell Companion to Modern Theology edited by Gareth Jones, pp. 133146 (Malden, MA: Blackwell Publishing, 2004), 134.

Paul Tillich, Systematic Theology 3 vols. (Chicago: University of Chicago Press, 1963), 14.

8 Charles C. Ryrie, Systematic Theology (Chicago: Moody Press, 1999), 9.

9 Charles Hodge, Systematic Theology Volume I edited by Anthony Uyl (Woodstock, ON: Devoted Publishing, 2016 ), 12.

10 John S. Mbiti, "Some current concerns of African theology," Expository Times 87/b, (1976): 164-168, 164.

${ }^{11}$ Alister E. Mcgrath, Historical Theology: An Introduction to the History of Christian Thought Second Edition (West Sussex: Wiley-Blackwell, 2013), 17.
} 
(354-430 AD). Though Africa contributed immensely to the establishment and development of Christianity in the early centuries, the impact of Christianity on the continent decreased to the extent that Christianity had to be revived through missionary activities undertaken by Western and American missionaries.

Christian missionaries who re-introduced Christianity into Africa had ethnocentric mindsets and so they considered everything African as incompatible with Christianity. A 19th century European first timer in Africa observed: "As we steamed into the estuary of Sierra Leone on November 18th [1889], we found Africa exactly as books of travel had led us to anticipate, a land of excessive heat, lofty palmtrees, gigantic baobabs, and naked savages. At five o'clock we dropped anchor at Free Town, called, on account of its deadly fevers, the "white man's grave." 12 The missionary continued to give his experience upon arrival saying "Immediately, our vessel was surrounded by boats filled with men and women, shouting, jabbering, laughing, quarrelling, and even fighting. ... Without exception, it was the most confusedly excited and noisy lot of humanity I had ever seen." ${ }^{13}$ The fact that missionaries downplayed the validity of the African culture is also evident in Kwame Bediako's assertion that, "The missionaries on their arrival on the African continent defined Africa as a dangerous place and its people as savages, uncivilized, and superstitious who had no religion and spirituality." 14 With this perception about Africa, missionaries took an uncompromising approach toward African traditions and culture. The missionaries imposed their theological and liturgical traditions on Africans and forced them (Africans) to disassociate themselves from African traditions and culture. The Basel Mission for example, built "Christian communities" (Akan: Salem) where their converts left their families and lived to avoid pollution by the traditional society. The missionaries rejected everything African without having adequate understanding of the African culture and traditions. Ignorance of the real nature of African worldview and practices created many false images of Africa and sometimes wrong observation resulted in exaggeration. African converts were banned from taking part in traditional activities such as festivals, puberty rites, drumming and dancing, among others. African converts were also forced to take Western (or "Christian") names before being accepted as Christians. Africans had to abandon their ways of dressing and to dress like Europeans before mounting the pulpit to preach. The missionaries also imposed Western liturgy and music on the African church and paid virtually no attention to the African music style.

The missionary approach to ministry in Africa (outlined above) prompted various reactions from Africans. Traditional leaders and their subjects opposed the missionaries through direct confrontations and criticisms. Some polygamists chose to remain "Christians" outside the church, arguing that belief in Christ and church attendance were two different things. The missionaries' puritan approach to African indigenous life prompted the Africanization of Christianity. The missionaries prepared grounds for the indigenization of African Christianity through the development of African mother tongues, the training of African missionaries and African mother-tongue Bible translations. The publication of African mother-tongue Bibles provided Africans with the tool to theologize in their own languages and formulate theologies that are not only biblically grounded but also contextually relevant. Aloo O. Mojola narrates how the Old Testament became a key source in African Christian theology because of the strong affinity that the Old Testament world has with the African world:

As soon as the first texts of the Old Testament appeared in African languages, the pioneer African readers of these texts could not avoid noticing the similarities between many of the stories of the Old Testament and stories from their own cultures, between many Old Testament religious practices and institutions and those of their own, in short, the Old Testament could easily have been read as an African book without much difficulty. ${ }^{15}$

\footnotetext{
12 Brown as cited by Ernest Nyarko, “A Critical Assessment of Western Perception of Africans' Religiosity: 19th And Early 20th Centuries" in E-journal Of Religious and Theological Studies (June 2015): 44-74, 47.

13 Brown as cited by Nyarko, “A Critical Assessment of Western Perception of Africans' Religiosity," 47.

${ }^{14}$ Kwame Bediako, Theology and Identity: The Impact of Culture upon Christian Thought in the Second Century and in Modern Africa (Oxford: Regnum Publishers, 1999), 227.

15 Aloo O. Mojola, "The Old Testament or Hebrew Bible in Africa: Challenges and prospects for interpretation and translation," Verbum et Ecclesia 35(3) (2014):1-7, 3. The original had OT which I have replaced with Old Testament.
} 
African Indigenous/Instituted Churches (AICs) emerged with their strong passion for the indigenization of Christianity. For AICs, "Christianity must become incarnate in African cultures; that Christ is present in every human situation, in every community and every human tradition... that Africans must experience Christ in their own cultural tradition." 16 Consequently, they introduced aspects of traditional African life into their worship system, allowing for drumming and dancing, clapping, and making their theology respond to key African spiritual needs such as healing, deliverance, protection, and others. The AICs did well in accommodating the African worldview. However, the indigenization process landed some of these churches into syncretism which became a major setback. Missionary Christianity and colonialism were closely linked, with the former being predominantly religious and the latter politically motivated. Between the late nineteenth century and the early twentieth century, the colonized organized themselves to resist colonial oppression and racism.

\section{The Modern Strand of African Christian Theology}

The modern quest for an African way of theologizing gathered momentum with the rise of the pan-African movement toward political independence and freedom after the Second World War. ${ }^{17}$ Christianity during the colonial days was clothed in western civilization such that people considered western culture as the embodiment of Christianity or Christian values. By their race, religion, culture and nationality, Africans identified missionaries with their (Africans') colonial masters. As one suffered cruel treatment from their colonial masters and suffered the imposition of western theology in the church, they looked up to a day when they would gain independence not only politically but also religiously. Theology then became a struggle against enslaving and dehumanizing forces. Theology became the tool for regaining the losses Africa had incurred through colonization. ${ }^{18}$

It was in the later 1950s and early 1960s that the search for a definitive African theology became a serious academic issue. ${ }^{19}$ Schreiter's foreword to Bujo's African Theology in Its Social Context considers a 1956 publication by a group of African scholars in French titled Les Pretres noirs s'interrogent as officially marking the beginning of modern African theology. ${ }^{20}$ Bujo identifies Mulago as the first individual (modern) African theologian. Mulago published in 1955 before the group published in 1956. James Nkansah-Obrempong identifies African personality in Anglophone Africa and the Negritude movement of Francophone Africa as two key factors that led to the emergence of African Christian theology. ${ }^{21}$ The Negritude movement refers to an anti-colonial cultural and political movement founded by a group of Francophone Africans to address the “'dilemma of the spirit' of Africa's Westernized intelligentsia, their sense of inner alienation, dislocation, and loss of identity, by means of a sustained evocation and affirmation of African traditional values and culture.",22

African revolutionary movement had a three-dimensional political philosophy-Pan-Africanism, Nationalism and Socialism - toward the liberation of the black race. These components were considered inseparable and indispensable for the liberation of Africa. The first two components give the context within which African Christian theology emerged. The third component also seems to have provided means of expressing sociopolitical and economic aspirations which played a leading role in developing black theology in southern Africa. Pan-Africanism comprises a set of ideas expressed by people of African descent living in the continent or in the diaspora toward uniting people of African descent and liberating blacks. African nationalism is based on the idea of national self-determination and the creation of nation states. It "emerged when the contradictions between Western-claimed democratic values and colonial autocratic oppression

\footnotetext{
16 Aylward Shorter, African Christian Spirituality (London: G. Chapman, 1975), 22

17 Emmanuel Martey, African Christian Theology: Inculturation and Liberation (Maryknoll, NY: Orbis Books, 1993$), 7-8$.

18 Martey, African Christian theology, 8.

19 Benezet Bujo, African theology in its social context (Maryknoll, NY.: Orbis Books, 1992), 5.

20 Bujo, African theology in its social context, 5.

21 James Nkansah-Obrempong, “The contemporary theological situation in Africa: An overview," Evangelical Review of Theology 31, (2007): 140-150, 140-141.

22 W. P. Bowers, “African Christian theology” in Evangelical Dictionary of Theology edited by Walter A. Elwell, pp. 28-34 (Grand Rapids, MI: Baker Academics, 2001), 31.
} 
became apparent to Africans." ${ }^{23}$ Africans became politically conscious and then capitalized on the situation to fight against Western imperialism. The African church reacted to the changes introduced by African nationalism by developing and preaching messages that brought social change in Africa. The African church- having perceived the nationalist attitude as both the result of and reaction against Western colonialism - called on the west to "recognize that as a result of its rule African people have been brought...to the point where they are critically assessing what colonialism has done to them." 24 The church recognized that the theological framework of early African theologians did not cater for the liberation of blacks. In addition to liberation, the church also promoted national unity.

From the mid-1960s many African scholars began to call for the formulation of a distinct theology for Africans. As Africans became more conscious of the need to have the gospel incarnate in their context using aspects of the African worldview and culture that are compatible with the teachings of the Bible, different conferences were organized and researches were published toward the development of the African way of theologizing. Bolaji Idowu, Edward W. Fashole-Luke, Kwesi A. Dickson, John S. Mbiti, John S. Pobee and others pioneered this agendum. African nationalism and the call for African theological distinctiveness engaged the 1963 All African Churches Conference. In his Towards an African Christian theology (1979), Pobee formulated an African Christian theology from an Akan perspective. Scholars continued to call for re-orientation, re-organization and contextualization of African Christian theology. In 1982, Yusufu A. Obaje formulated an African ecclesiology in which the church was regarded as a theocentric community as ancient Israel was before the institution of monarchy. Dickson's Theology in Africa (1984), Mbiti's Bible and Theology in African Christianity (1987), Emmanuel Martey's African Christian theology: Inculturation and Liberation (1993), Kwame Bediako's Christianity in Africa: The Renewal of a Non-Western Religion (1995) and Jesus and the Gospel in Africa: History and Experience (2000) and other publications by other African scholars have contributed to the development of African Christian theology.

In South Africa, the white supremacist domination prompted the emergence of black theology in the early 1970s - that was the first phase. The first phase of black theology began as a theological expression of the ideologies of the Black Conscious Movement. The Black Conscious Movement was an all-inclusive movement that drew people of different backgrounds together. In the first phase (that is, before 1977), the movement sought to conscientize blacks to their predicaments and to unite them to work toward achieving a holistic liberation of blacks. ${ }^{25}$ The post- 1977 task of the movement was to translate the Cultural Revolution in blacks into a political action. The movement synthesized the thesis of white racism and the antithesis of lack of solidarity to define true humanity as one that is "colorless" and "raceless" and had no place for power politics. The second phase of black theology started in the early 1980s when the Black Theology Task Force of the Institute for Contextual Theology organized various conferences toward African liberation. Like African Christian theology in the northern part of the continent, black theology resisted all forms of political, cultural and religious imperialism. The black theology movement "sought theological resources for investing South African blacks with a sense of human dignity in the face of apartheid, and for empowering them to achieve social justice and liberation." 26 Prominent advocates of this movement included Manas Buthelezi, Allan Boesak, and Desmond Tutu.

African Christian theology is not the same as black theology. The former developed in independent or neo-colonised Africa whereas the latter developed in apartheid South Africa. The former places more emphasis on Africanization or indigenization of Christianity but the latter emphasizes African culture and liberation. Not long after the movement emerged, a scholarly debate began regarding the relationship between African Christian theology and black theology. Black theologians contended that by over concentrating on Africa's past, African Christian theology cared less about the future of Africa. ${ }^{27}$ In reply, African Christian theology said black theology does not deal with the central issues in African society. Meanwhile, African

\footnotetext{
23 Martey, African Christian theology, 11.

${ }^{24}$ Document by All African Conference of Churches cited in Martey, African Christian theology, 12.

25 Martey, African Christian theology, 25.

26 Bowers, "African Christian theology," 31.

27 Bowers, "African Christian theology," 31.
} 
Christian theology embraced the liberation theology on issues related to Western economic and political exploitation of Africa. By the 1990s, black theology hardly remained functional. However, its interactions with African Christian theology had made the latter adjust its focus to include a political theology that sought to liberate Africa from Western oppression. ${ }^{28}$

\section{Aspects of the African worldview}

Africa is made up of different people with diverse socio-cultural realities. The existence of a variety of ethnic groups and cultures in Africa makes people ask whether it is appropriate to speak of an African worldview. For example, John S. Pobee argued that the multiplicity of African identity due to the existence of multiples of ethnic groups with their own cultural peculiarities makes it virtually impossible to talk of a unified African worldview. ${ }^{29}$ The author, while acknowledging the difficulties associated with harmonizing the diverse worldviews of African people, argues for the possibility of examining the common aspects of the worldviews of Africans in a coherent manner. Even Pobee and others who argue against identifying Africans with a common worldview, sometimes talk of "a certain Africanness" that makes Africans different from other people. Some beliefs and practices shared by Africans are outlined below.

The first aspect of the African worldview is the question of the nature of ultimate reality. Africans consider the Supreme Being (or God) as the Ultimate reality. God, in African life and thought, is present everywhere and so no one needs to point him to even a child. Different people refer to God by different names, each expressing one divine attribute. The Gas of Ghana refer to the parenthood of God by referring to him as Ata-Naa Nyomms ("Father-Mother God"); the Ewes of Ghana and Togo call him Mawu ("The most high God; the Creator"); the Agikuyu of Kenya call him Ngai ("who alone created all things') and the Yoruba call on Olodumare ("the Almighty God"). God is both immanent and transcendent in some African cultures and in others, he is only transcendent, so far from everyday life. ${ }^{30}$

Secondly, African identity is deeply rooted in the communal sense of life. African worldview prioritizes community over the individual. The traditional family system in Africa is the extended family which extends beyond a couple and their children to include grandparents, uncles, aunties and others. One's family also includes the ancestors and the unborn. Because of the communal sense of life, Africans dread being excommunicated from the community. Traditionally, Africans live in compound houses where they can enjoy the company of others. The Ubuntu Philosophy with its emphasis on "being self through others" aptly captures the African communal sense of life. Ubuntu is a form of humanism expressed in the Zulu statement ubuntu ngumuntu ngabantu ("I am because of who we all are"). Archbishop Desmond Tutu explained Ubuntuism as follows: Ubuntu is to say "My humanity is caught up, is inextricably bound up, in what is yours... A person is a person through other persons." ${ }^{31}$ Unlike the Western aphorism, "I think, therefore I am" (Cogito, ergo sum), Ubuntuism says "I am human because I belong. I participate, I share." Therefore "what dehumanizes you inexorably dehumanizes me." 32 Ubuntuism as expressed in the above quote highlights at least three facts: First, to be human requires recognizing and affirming the humanity of others. Secondly, life must be prioritized over wealth. Thirdly, leaders owe their status and power to the will of their subjects. Embedded in Ubuntuism are the concepts of sympathy, interconnectedness, compassion, benevolence, sharing, generosity, consensus building, hospitality, kindness, brotherhood, harmony, solidarity, empathy, human dignity and others. In traditional African worldview, sin and salvation are both communal affairs. In Africa "To be delivered from sin into fullness of life is to be freed and empowered to live a community-centred life. It is to be given the capacity to contribute actively to the sensus communis [common sense]." ${ }^{33}$ Among the Ewes of Ghana, for instance, if one offends another person, the offender is expected to apologize to the offended person to settle

\footnotetext{
${ }^{28}$ Bowers, "African Christian theology," 31.

${ }_{29}$ John S. Pobee, "The Sources of African Christian theology," A Reader in African Christian Theology, edited by John Parratt. (London: SPCK, 1987), 23-28.

${ }^{30}$ Yusufu Turaki, Foundations of African Traditional Religion and Worldview (Nairobi: WordAlive Publishers, 2006$), 54$.

31 Desmond Tutu, No Future without Forgiveness (New York: Doubleday, 1999), 31.

32 Tutu, No Future without Forgiveness, 31.

33 Emmanuel Asante, "The Gospel in Context," Interpretation: A Journal of Bible and Theology 55(4), (2001): 362.
} 
the matter. ${ }^{34}$ If the offended person refuses to accept the apology, the offender seeks help from the leader of the family, clan or community to settle the matter. Here, the offender is usually asked to pacify the offender with eggs and/or drinks. If the offended refuses to accept the apology at this point, the matter is left to the gods to decide. The gods would normally kill the relatives of the offended before finally killing the offended himself/herself. The reason is that without one's family one's life is meaningless; therefore, as the person's relatives are wiped off, his/her life becomes worthless until he/she is eventually killed. This underscores the fact that the family has the responsibility of shaping the conduct of their members. The unforgiving spirit of the offender, in this case, should have been checked by the family which raised him/her. The communal worldview is therefore applied by the gods in dealing with this matter.

The African worldview also comprises the belief in spiritual beings. These spirits may be benevolent or malevolent. With the fear of evil spirits, people always seek greater powers that can protect them from the myriad of evil forces that populate the world around them (or malicious, evil forces that parade the cosmos). It is believed that what happens physically has a spiritual antecedent. Therefore, people attribute diseases, illnesses, miscarriages, marital problems, accidents, alcoholism, death and misfortunes to the works of spiritual forces. Again, reality in African cosmology and practice is holistic devoid of "any dualism between material/spiritual, individual/community, religious/social, and intellectual/emotional." ${ }^{35}$ Therefore, Africans are generally not satisfied with "a purely materialistic and secular worldview."36

\section{Fundamental (Non-negotiable) Features of African Christian Theology}

\section{African Christian Theology must be Biblical}

African Christian theology must be based on the teachings of the Bible. The Bible is the primary and final authority (though not the only authority) for doing theology for the benefit of the African church. Other sources for theological formulation include reason, tradition, and experience. However, these sources must be subjected to the scrutiny of biblical teachings. As the Word of God, the Bible is authoritative, inspired, sufficient and necessary for theological formulations. African Christian theology shares its biblical basis with theology done elsewhere. Time, geographical, language and cultural gaps between the biblical world and the contemporary world sometimes make the message of the Bible unclear to the modern reader. For this reason, the theologian must be conversant with the rules of interpretation of the Bible. As a rule, a biblical text cannot mean to the contemporary reader that which it did not mean to its first audience. Therefore, the modern reader needs to interpret the Bible in its original context before attempting to apply it to the contemporary situation. The socio-cultural and religious context of the biblical text must be considered before any legitimate interpretation can be done. The fact that the Bible was revealed progressively requires the theologian to explore what the entire Bible says about a subject before any theological formulation is made. Above all, the theologian must rely on the power and illumination of the Holy Spirit who is both the author and the interpreter of Scriptures. One has to read the Bible carefully and prayerfully before drawing conclusions from it.

African theologians must develop and apply an interpretative framework that takes care of the African cosmology and practice. Some African traditional concepts and experiences can be used as a basis for developing biblical concepts. To illustrate this point, one may consider Jesus's statement "You are the light of the world.... You are the salt of the earth" (Matt. 5:13-14). The light metaphor is traditionally understood as the directive role of the Christian. As the light of the world, Christians bring works of darkness into light. Christians are, however, not self-luminous in that they do not have light in themselves but rather reflect the light they receive from Christ who is the only source of light. This interpretation is well understood in Africa where most communities lack electricity and have to rely on light sources such as lanterns, coal and others. The interpretation of the salt metaphor, based on Western hermeneutical framework, emphasizes the role of salt in preserving and adding taste to food. The disciple of Christ then is expected to ensure that Christian traditions are preserved and passed on to the next generation. Again, the Christian must transform a sour or

\footnotetext{
${ }^{34}$ I have gleaned what follows from Daniel Sakitey, Matthew's Version of the Lord's Prayer in Ewe-Ghanaian Context (PhD Thesis: University of Pretoria, 2018), 42-43.

35 Casely B. Essamuah, Genuinely Ghanaian: A History of the Methodist Church Ghana (1961-2000) (Trenton, NJ: Africa World Press, 2010), xxxvi.

${ }^{36}$ Essamuah, Genuinely Ghanaian, xxxv.
} 
tasteless situation into a sweet one. In many African societies (including Ghana, Nigeria, Kenya and others), this understanding is well known and acceptable. However, reading this text from the context of another part of Africa allows new insights to emerge. An explanation from a theologian from the southern part of Africa shows that both the light and salt metaphors relate to the disciple's role in directing people to Christ. The theologian explained:

In my village, when there is drought, the monkeys know where there is water. But, they will not lead humans to that water. [They will only go to the water when no human being is following them]. So, the people will trap a monkey and tie it up. Then, they will feed it [with] salt. After a day or two, the monkey will become very thirsty. At this point, the humans will release the monkey. Then, the monkey will not care if the human beings are following it or not; it will make straight for the source of water in order to satisfy its thirst. ${ }^{37}$

The theological point then is that the disciple of Christ is like the salt that makes people thirst for the living water, who is Christ (John 4). Therefore, Christianity that does not make people thirst for the living water or Christianity that does not help people find direction to the source of living water is not worth its salt. This understanding is unique, contextually informed and quite different from the understanding that the salt in the metaphor represents preservation and the addition of flavor. This does not mean that the privative nature of salt is relevant in the society in question. Rather, it means that from the experience of the said community, in the African setting (or at least in the African community in question) there is more to the salt metaphor than what Western commentators have taught all these years. From the example given, one can argue for the need to promote African cultural reading of the Bible in African Christian theologizing. This may sometimes require innovation and creativity on the part of the theologian.

\section{African Christian theology must be "Glocal"}

African Christian theology must be characterized by globality and contextualization. Thus, African Christian theology must be both suitable for the global church and contextual for the local community. It is in this sense that one may say African Christian theology is "glocal." 38 What makes African Christian theology faithful to the basic message of the Christian faith makes it global (or applicable to the universal/global church). ${ }^{39}$ Thus whatever makes African Christian theology to be Christian also makes it to be globally acceptable. Whether one's theology is African or Western, it must not contradict the fact of the sinfulness of humanity, the death and resurrection of Christ, salvation by grace through faith, the second coming of Christ and others. Kosuke Koyama serves us well with this quote: "Latin American liberation theology is a responsible theological effort to indigenize theology within the Latin American political and economic situation and at the same time carries a relevant message about the global situation of humanity today." It follows from Koyama's assertion that contemporary issues such the COVID-19 pandemic, HIV/AIDS, racism, overpopulation and others that are of interest to African theologians should be seen and discussed as global issues.

The global nature of African Christian theology must nevertheless not deprive it of its contextual demands. Christian theology must be contextually informed, meaning, theological formulations are made to address issues confronting the society for which they are formulated. Contextualization "attempts to communicate the Gospel in word and deed and to establish the church in ways that make sense to people within their local cultural context, presenting Christianity in such a way that it meets people's deepest needs and penetrates their worldview, thus allowing them to follow Christ and remain within their own culture."40 To achieve both globality and contextualization, African theologians must mediate between the universal message of Christianity (with its predominantly western flavor) and African realities. This mediatorial role requires adequate understanding of both the biblical and the African worlds. African Christian theology must

\footnotetext{
37 John Jusu and Matthew Elliott “The Africa Study Bible: God's Word through African Eyes," Reading the Bible in Context Issue 2 (2016):4-7, 4.

38 To be "glocal" means to reflect both local and global considerations.

39 Norman Pittinger, Unbounded Love: God and Man in Process (New York: The Seabury Press, 1976), 15.

40 Jonas Adelin Jørgensen, Jesus Imandars and Christ Bhaktas: Two Case Studies of Interreligious Hermeneutics and Identity in Global Christianity (Frankfurt: Peter Lang, 2008), 96.
} 
be informed by both the biblical worldview and the worldview(s) of Africans.

\section{African Christian theology must include oral, symbolic and written theologies}

All too often (Western) Christian theology is equated with professional scholarly publications people's reflection about God. Theologians are therefore seen as people writing books on one theological topic or the other. Theologians are then rated based on their ability to interact with past and present philosophers and theologians. Rahner alludes to this view when he states that "A theology is not technically theology when the experience about God had not been systematically, critically and scholarly interpreted or articulated." 41 Rahner's assertion that theology must be "systematically, critically and scholarly interpreted or articulated" reflects theology done in societies with a high level of literacy. As a matter of fact, the academic approach to theology makes it globally accessible. Since African Christian theology is global theology, there is the need to organize it in a systematic and scholarly manner, interacting with theologians from other parts of the world. And indeed there is a category of African Christian theology that is highly technical and academic to serve both the local and global Christian communities. Most African theologians were trained in Western Universities and/or were trained by Western scholars using Western theological frameworks. Consequently, most African documented theological reflections are critical, systematic and scholarly reflections on God. African theologians interact with their non-African counterparts mainly through academic theology.

While academic theology serves an important purpose, in Africa, where the illiteracy level is very high, it discourages mass participation in theological discourses. Academic theology seems abstract to most illiterate Africans. That is why even African churches who have well-trained ministers of the Gospel may not do well in most African communities if the ministers are unable to transform the academic theology they have studied into other forms which their African audience can easily grasp. According to John S. Mbiti, there are three categories of African Christian theology: oral theology, symbolic theology and written/academic theology. ${ }^{42}$ The first two forms of theology are more suitable for most African societies. "Oral theology" has to do with reflections about God through sermons, teachings, prayers, discussions, songs, conversations, witnessing, testimonies, and any other oral form. ${ }^{43}$ Symbolic theology is the expression of one's conceptions about God expressed through artefacts, drama, symbols (cultural symbols), rituals, colors, dress, church furnishings, and worship styles. Written/academic theology (as noted earlier) is a technically and systematically constructed reflection about God usually based on Western theological traditions and mostly meant for the consumptions of academics. ${ }^{4}$

Instead of making theology academic and technical and then having a monologue where the teacher instructs the people what he/she thinks the questions and answers are, African Christian theology must sometimes be non-academic so as to allow the participation of the entire Christian community. The nonacademic form of theology allows African Christians themselves to better understand the Christian message and how it addresses their physical and spiritual needs. Without including African cultural elementsincluding African traditional hymns, myths, proverbs, invocations, arts, symbols, prayers, incantations, ritual, songs, dreams, beliefs and customs, names, riddles and sacred places - in theological formulations, African indigenous religious traditions will be sidelined in the interreligious dialogue. African Christian theologizing should not sideline the African primal religious thoughts altogether; there are aspects of African traditional religion which can mediate the Christian gospel to the African. Therefore, Africans must be free to use their vernaculars to undertake theological reflections that draw on their own figures of speech, analogies, patterns of logic and arrangement based on their oral traditions. This does not in any way mean African Christian theology must be solely oral theology or symbolic. The point rather is that oral and symbolic theologies must be bedfellows with academic theology, the former serving as the basis for the latter. Without this partnership, academic theology will remain exclusively for scholars and hence be of virtually no relevance to the masses.

\footnotetext{
${ }^{41}$ Rahner as cited in Eze Ikechukwu, Being a Christian in Igbo Land: Facts, Fictions and Challenges (Berlin: Logos Verlag, 2013), 247.

42 John S. Mbiti, “African Christian theology,” In: S. Maimela and K. Adrio (eds.). Initiation into Theology: The Rich Variety of Theology and Hermeneutics, 141-158 (Pretoria: J L van Schaik Publishers, 1998), 146-149.

43 Richard J. Gehman, Doing African Christian Theology: An Evangelical Perspective (Nairobi: Evangel Publishing House, 1987), 28.

${ }^{44}$ Mbiti, "African Christian theology," 146-149.
} 


\section{African Christian theology must be a theology of relevance}

No theology can continue to be meaningful to humanity in a fast-changing society without a constant adjustment of its message to give a fresh application to new situations. For African Christian theology to make the needed impact, it must be relevant to the needs of the people. In other words, African Christian theology "is a call to meet the felt needs of the Africans in an African manner according to the Scriptures." 45 African theologians, therefore, need to understand the contemporary society - in terms of its past and present realities - and then apply God's word to its needs. The point is that African Christian theology must serve the peculiar needs of Africans based on the African worldview. These peculiar needs of Africans have been summarized by Obaje as including "spiritual undernourishment, material poverty, suffering, corruption, diseases, demonic oppressions, witches, wizards, wickedness, ignorance, oppressive civilian and military dictatorial governments, inequality, aggressive tribalism, religious fanaticism, inter-ethnic wars, political and social unrest, neocolonialism, inefficiency, under-development of resources" and others. ${ }^{46}$ If theology does not help the African believer to overcome the fear of evil forces; if theology does not relieve the plight of the poor; if theology does not speak to the issue of corruption, bribery, food insecurity and others, then it is not of any relevance at all to the Africa reader. African Christian theology must therefore engage the public space and contribute to the search for solutions to societal challenges.

\section{African Oral Theology: An Illustration from Abibinnwom}

The Abibinnwom (African sacred lyrics) tradition of the Akan of Ghana may serve to explain how Africans can express their worldview in oral theology. Abibinnwom was introduced into Ghanaian Christianity during the ministry of the Methodist missionary Rev. Thomas Birch Freeman. Abibinnwom might have originated from Akan storytelling tradition. In the traditional setting, people gather at night to listen to stories told usually by old women. There is a stage in Akan storytelling tradition when the storyteller pauses and then raises a song referred to as mmoguo (interlude) to awaken the listeners. The mmoguo tradition might have given birth to Abibinnwom singing in the church setting. Another possible origin of Abibinnwom is African war songs (that is, songs sung during wars). Whatever one's position on the origin of Abibinnwom the fact still remains that it is a key means of theologizing that allows grass-root participation in Christian theological formulations in Ghana in particular and African at large. Abibinnwom is biblically sound (usually composed based on Bible passages), contextually informed (based on the African worldview and culture) and attends to the existential needs of the receptor community. Both men and women alike may raise Abibinnwom as their response to a sermon; however, it is primarily a women's tradition. The singing of Abibinnwom has empowered many women today to formulate theology to address their own life circumstances.

The following Abibinnwom composed by Rev. Samuel B. Essamuah illustrates how Abibindwom draws from the biblical and African worldview to provide solutions to the existential needs of Africans.

Oduycfo kese, fa wo nsa beto mo do. Besa me yare ma me na menya ahosdzen dze asom wo oo. Yare nketse nketse rehaw me wo sunsum mu; nscm nketse nketse rehaw me wo sunsum mu. Mekyinkyin, ekyinkyin, ekyinkyin mennya ano edur koraa, Egya ee! Besa me yare ma me, na menya ahosdzen na m'asom wo oo.

Great Healer, come and touch me. Heal my ailments that my strength may be renewed for your service. I am deeply troubled, deeply troubled by spiritual sicknesses, anxieties and worries. I have been to many places for healing, but none has been of help. Come, Lord, release me from these spiritual ailments and troubles; that I may enjoy the health, strength and vitality needed to serve you.

This song was composed just before Rev. Essamuah began a nationwide healing and deliverance campaign. Th expression "healing and deliverance" is used collectively to refer to the process of using spiritual weapons "to provide release for demon-possessed, demon-oppressed, broken, disturbed and troubled persons, in order that victims may be restored to "proper functioning order," so that "they may enjoy God's fullness of life

45 Gehman, Doing African Christian Theology, 35.

46 Obaje as cited in Emiola Nihinlola, Theology Under the Mango Tree: A Handbook for African Christian Theology (Lagos:

Fine Print \& Manufacturing Ltd., 2013), 40. 
understood to be available in Christ." ${ }^{\prime 47}$ Many Africans suffer from one sickness or the other. One of the greatest reasons a Christian convert may turn back to traditional religion is sickness. Traditional Africa has a high mortality rate. Sickness often leads to death. Lack of complete understanding of sickness and death makes African believers become frightened at the prospect of sickness. Before their conversion, their traditional religion provided their health needs. The traditional medicine man was always available to assist the sick find cure. Since the cause of sickness is not only physical but spiritual as well, traditional healers provided more than natural solutions to people's health problems. The healer sought assistance from the spiritual realm to deal with the spiritual root of sicknesses. Therefore, it stands to reason that their new religion (Christianity) should cater for their health needs. Unfortunately, Western-missionary theological framework considered sickness from the physical perspective alone and gave no room for the spiritual causes of diseases. They introduced western medicines in dispensaries and hospitals as the only legitimate solution to African health needs. This approach minimized the centrality of the supernatural in healing diseases. Rev. Essamuah ministered in the Methodist Church Ghana which like other historic mission churches inherited Western theological tradition. Not many decades before this song was composed the Methodist Church Ghana had experienced a decline in membership. People left the Methodist Church to join Pentecostal Churches because of the former's failure to attend to their existential needs. Therefore, Rev. Essamuah was fully aware of the effect of a church's failure to cater for African religious expectations. Therefore, he composed his song to address the inadequacies embedded in Western theology of diseases, healing and deliverance.

Rev. Essamuah's song draws on the healing ministry of Christ as attested by the gospel writers-Jesus healed deafness and dumbness (Mark 9:25), convulsion (Mark 1:26; 9:20; Luke 9:39), blindness and deafness (Matt. 12:22). Drawing on the African traditional worldview, Rev. Essamuah referred to Christ as Oduyefo $k \varepsilon s e$ ("Great Healer"), implying that the healing power of Christ surpasses that of any traditional healer in the Akan/African community. The part of the lyrics which say "Yare nketse nketse rehaw me wo sunsum mu nscm; nketse nketse rehaw me wo sunsum mu" ("I am deeply troubled, deeply troubled by spiritual sicknesses, anxieties and worries") also draws from the African worldview that disease is caused by spiritual entities such as akaberekyerefos and adutofos (charmers, enchanters, and sorcerers) and abayifos (witches and wizards). The composer also places himself in the shoes of the sick and says "Mekyinkyin, ekyinkyin, ekyinkyin mennya ano edur koraa, Egya ee!" ("I have been to many places for healing, but none has been of help"). It is not unusual for traditional Africans to move from one healer to another in search of a solution to their health needs. Even today, African Christians move from one prayer camp to another in search of a solution to their existential needs. The one who finds the solution to one's problem after a long search is considered the most powerful being. The composer then proceeds to invite Jesus to heal saying "Besa me yare ma me, na menya ahoodzen na m'asom wo oo." ("Great Healer... Heal my ailments that my strength may be renewed for your service). By presenting Christ as a "Great Healer", Rev. Essamuah assures his audience that Jesus will attend to their health needs. This makes his message relevant to the ordinary Akan/African. The song had a great impact on the Ghanaian Christian community and led to the conversion of many people to Christ. This kind of oral theology which is non-technical can easily be understood by the ordinary African Christian must be encouraged. The bottom line is that that African Christian theology must be geared towards the well-being of Africans.

\section{Implications for African Christian Theology}

The traditional African belief in God was outlined earlier. According to Elizabeth Mburu, Africans approach God on a transactional basis, meaning they render services to God based on what they hope to receive in return rather than to maintain a good relationship with him. ${ }^{48}$ Mburu supports this assertion with Gehman's opinion that traditional African worship is "utilitarian, seeking God for the help they might receive, rather than extolling the greatness and goodness of God." ${ }^{49}$ The obvious conclusion is that Africans worship God

\footnotetext{
47 J. K. Asamoah-Gyadu, African Charismatics: Current Developments within Independent Indigenous Pentecostalism in Ghana (Leiden: Brill, 2005), 165.

48 Elizabeth Mburu, African Hermeneutics (Carlisle: HippoBooks, 2019), 28.

49 Gehman cited in Mburu, African Hermeneutics, 28.
} 
primarily to seek solutions to their existential needs. While such a worldview is not completely unbiblicalbecause only God has real solutions to human needs - it is theologically unacceptable to approach God primarily because of one's expectation that God will make for one's daily existence. Perhaps, it is this transactional approach to God that has rooted prosperity theology so firm in the African environment. Prosperity theology is the teaching that God always wills the financial and physical well-being of believers and therefore any believer who exercises faith, maintains a positive mindset, and makes donations to religious causes will increase materially. A balanced view of the biblical teaching about wealth and poverty should be developed and promoted in the African Church. As a matter of urgency, African Christian theology must maintain a balance between "this-worldly" concerns and eschatological concerns. The economic situation on the continent requires a theology of hope that will relieve people of their plight without making them forget the reality of the world to come.

The strong affinity between the African and biblical worldviews of communal lie, interdependence, sharing of resources, and others must be given attention in African Christian theology. African Christian hamartiology and soteriology can be developed using Ubuntu as the foundation. The communal nature of the ecclesiastical community can be well developed within the African context using the African idea of "existence-in-relationship." ${ }^{50}$ Like everything else in life, worship in traditional African practice is done in the context of the community. Thus, in Africa, horizontal relationships are key to one's fulfillment in worship. Before one approaches God through sacrifices, offerings, prayers and others, one has to maintain harmony in the society. The social dimension of the consequences of sin is key for developing contextually relevant and biblically sound eco-theology for the African society.

Given that African traditional worldview shows no distinction between the "spiritual" and the "sacred", African Christian theology must engage the public space. Christian spirituality must have both spiritual and social ramifications. Currently a careful observant will see two "Africas" - the Africa in which Christianity is "flourishing" and the African which is morally and socially withering. Christianity has spread to almost every part of the continent with mega churches and Christian gatherings seen every day everywhere. People cry onto the Lord and testify of miracles happening in their lives. Unfortunately, the same society in which Christianity is "flourishing" is full of social and moral problems including armed robbery, sexual immorality, abortion, corruption, bad governance, and others. African Christian theology needs to engage the public sphere on these and other related challenges.

More so, the African worldview of the spirit world must be catered for in African Christian theology. Salvation, in African primal thought, goes beyond redemption from sin to deliverance from anything that prevents one from experiencing the fullness of life. In African thought, "God does not save because he [sic] is Saviour; rather, he becomes Saviour when he does save. The concept of saving is a dynamic one which is rooted in a particular moment of desperation." ${ }^{11}$ Mbiti alludes to the need for contextualized African Christian soteriology when he asserts "salvation in African Religion has to do with physical and immediate dangers (of the individual and more often of the community) - dangers that threaten individual or community survival, good health, and general prosperity or safety." ${ }^{, 52}$ Mbiti's assertion is meant to give the contextual implications of salvation for Africans. Salvation in African thought "is not just an abstraction: it is concrete, told in terms of both what has happened and is likely to be encountered by people as they go through daily experiences." 53 Therefore, African Christian soteriology must address issues like poverty, oppression, discrimination and more importantly deliverance from evil forces. In this light, the conquering power of Jesus Christ must be given attention in African soteriology to provide Africans with a divine conqueror who can expel their fears of evil spirits. ${ }^{54}$

\footnotetext{
${ }_{50}$ Gehman cited in Mburu, African Hermeneutics, 37.

51 John S. Mbiti, “ó $\sigma \omega \tau \eta \rho \dot{\eta} \mu \omega v$ as an African Experience," in Christ and Spirit in the New Testament, ed. Barnabas Lindars and Stephen S. Smalley (Cambridge: Cambridge University Press, 1973 ), 397.

52 John S. Mbiti, "Some Reflections of African Experience of Salvation Today," in Living Faiths and Ultimate Goals edited by S. J. Samartha (Geneva: World Council of Churches, 1974), 108-119, 112.

53 Mbiti, "Some Reflections of African Experience of Salvation Today," 112.

${ }^{54}$ Kwame Bediako, Jesus and the Gospel in Africa: History and Experience (Maryknoll, NY: Orbis Books, 2004), 8-17.
} 


\section{CONCLUSION}

African Christian theology is relevant for the development and survival of Christianity in Africa. If Christianity will be meaningful and relevant, then it must cater for the needs of the receptor community. That is the reason why African theological frameworks need to take the African socio-cultural context seriously. In the process, African Christian theology must cater for African's past, present and future. This paper has outlined some non-negotiable features of authentic African Christian theology-including, being biblically grounded, contextually and globally acceptable, academic and non-academic in form, contextually and globally acceptable, being not only academic but also oral and symbolic in form, and being relevant for the African Christian community. If these foundations are developed and promoted it is certain that Christianity will not only flourish "spiritually" but will also have socio-cultural benefits.

\section{ABOUT AUTHOR}

Isaac Boaheng holds a $\mathrm{PhD}$ in Theology from the University of the Free State, South Africa, a Master of Theology degree from the South African Theological Seminary, South Africa, a Master of Divinity degree from the Trinity Theological Seminary, Ghana and a Bachelor of Science degree in Geomatic Engineering from the Kwame Nkrumah University of Science and Technology, Ghana. He is a lecturer in Theology and Christian Ethics at the Christian Service University College, Ghana. Boaheng has over fifty publications in Systematic Theology, Ethics, Biblical Studies, Translation Studies, African Christianity, Linguistics, Pentecostalism and Christian Mission, among others.He is an ordained minister of the Methodist Church Ghana serving the Nkwabeng circuit of the Sunyani diocese.Boaheng is married to Gloria, and they are blessed with four children: Christian, Benedict, Julia and Kalix.

\section{BIBLIOGRAPHY}

Anselm of Canterbury, "Proslogion" translated by M. J. Charlesworth in The Major Works, ed. Brian Davies and G. R. Evans. pp. 82-104. Oxford: Oxford University Press, 1998.

Asamoah-Gyadu, J. K. African Charismatics: Current Developments within Independent Indigenous Pentecostalism in Ghana. Leiden: Brill, 2005.

Asante, Emmanuel. "The Gospel in Context," Interpretation: A Journal of Bible and Theology 55(4), (2001): 362.

Bediako, Kwame. Jesus and the Gospel in Africa: History and Experience. Maryknoll, NY: Orbis Books, 2004.

Bediako, Kwame. Theology and Identity: The Impact of Culture upon Christian Thought in the Second Century and in Modern Africa. Oxford: Regnum Publishers, 1999.

Bowers W.P., "African Christian theology" in Evangelical Dictionary of Theology edited by Walter A. Elwell, pp. 28-34. Grand Rapids, MI: Baker Academics, 2001.

Brown, Stephen F. "Medieval Theology." In The Blackwell Companion to Modern Theology edited by Gareth Jones, pp. 133-146. Malden, MA: Blackwell Publishing, 2004.

Bujo, Benezet. African theology in its social context. Maryknoll, NY: Orbis Books, 1992.

Essamuah, Casely B. Genuinely Ghanaian: A History of the Methodist Church Ghana (1961-2000). Trenton, NJ: Africa World Press, 2010.

Gehman, Richard J. Doing African Christian Theology: An Evangelical Perspective. Nairobi:Evangel Publishing House, 1987.

Hodge, Charles. Systematic Theology Volume I edited by Anthony Uyl (Woodstock, ON: Devoted Publishing, 2016.

Ikechukwu, Eze. Being a Christian in Igbo Land: Facts, Fictions and Challenges (Berlin: Logos Verlag, 2013. Jørgensen, Jonas Adelin. Jesus Imandars and Christ Bhaktas: Two Case Studies of Interreligious Hermeneutics and Identity in Global Christianity. Frankfurt: Peter Lang, 2008. 
Jusu, John and Elliott, Matthew. "The Africa Study Bible: God's Word through African Eyes," Reading the Bible in Context Issue 2 (2016):4-7.

Kunhiyop, Samuel Waje. African Christian Theology (Nairobi: WordAlive Publishers, 2012), 1.

Martey, Emmanuel. African Christian Theology: Inculturation and Liberation. Maryknoll, NY: Orbis Books, 1993.

Mbiti, John S. "Some current concerns of African theology," Expository Times 87/b, (1976): 164-168.

Mbiti, John S. "Some Reflections of African Experience of Salvation Today," in Living Faiths and Ultimate Goals edited by S. J. Samartha. Geneva: World Council of Churches, 1974.

Mbiti, John S. "ó $\sigma \omega \tau \eta \rho \eta ́ \eta \omega v$ as an African Experience," in Christ and Spirit in the New Testament, ed. Barnabas Lindars and Stephen S. Smalley. Cambridge: Cambridge University Press, 1973.

Mbiti, John S. "African Christian theology,” In: Maimela, S and Adrio, K. (eds.). Initiation into Theology: The Rich Variety of Theology and Hermeneutics, pp. 141-158. Pretoria: J L van Schaik Publishers, 1998.

Mburu, Elizabeth. African Hermeneutics. Carlisle: HippoBooks, 2019.

Mcgrath, Alister E. Historical Theology: An Introduction to the History of Christian Thought Second Edition. West Sussex: Wiley-Blackwell, 2013.

Mojola, Aloo O. "The Old Testament or Hebrew Bible in Africa: Challenges and prospects for interpretation and translation," Verbum et Ecclesia 35(3) (2014):1-7.

Nihinlola, Emiola. Theology Under the Mango Tree: A Handbook for African Christian Theology. Lagos: Fine Print \& Manufacturing Ltd., 2013.

Nkansah-Obrempong, James. "The contemporary theological situation in Africa: An overview," Evangelical Review of Theology 31, (2007): 140-150.

Nyarko, Ernest. "A Critical Assessment of Western Perception of Africans' Religiosity: 19th And Early 20th Centuries." E-journal Of Religious and Theological Studies (2015): 44-74.

Pittinger, Norman. Unbounded Love: God and Man in Process. New York: The Seabury Press, 1976.

Pobee, John S. "The Sources of African Christian theology." A Reader in African Christian Theology, edited by John Parratt. pp. 23-28. London: SPCK, 1987.

Ryrie, Charles C. Systematic Theology. Chicago: Moody Press, 1999.

Sakitey, Daniel. Matthew's Version of the Lord's Prayer in Ewe-Ghanaian Context. PhD Thesis: University of Pretoria, 2018.

Shorter, Aylward. African Christian Spirituality. London: G. Chapman, 1975.

Tillich, Paul. Systematic Theology 3 vols. Chicago: University of Chicago Press, 1963.

Turaki, Yusufu. Foundations of African Traditional Religion and Worldview. Nairobi: WordAlive Publishers, 2006.

Tutu, Desmond. No Future without Forgiveness. New York: Doubleday, 1999. 